\title{
Effects of purified Omphalia lapidescens protein on metastasis, cell cycle, apoptosis and the JAK-STAT signaling pathway in SGC-7901 human gastric cells
}

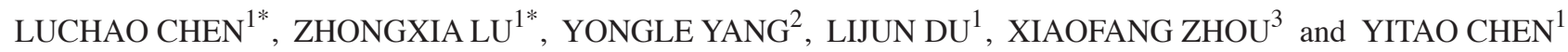 \\ ${ }^{1}$ Microbiology and Immunology Laboratory, College of Life Sciences, Zhejiang Chinese Medical University, \\ Hangzhou, Zhejiang 310053; ${ }^{2}$ Institute of Preventive and Veterinary Medicine and The Key Laboratory \\ of Animal Virology of Ministry of Agriculture, College of Animal Sciences, Zhejiang University, Hangzhou, \\ Zhejiang 310058; ${ }^{3}$ Department of Pharmacy, Zhejiang Cancer Hospital, Hangzhou, Zhejiang 310022, P.R. China
}

Received February 18, 2017; Accepted November 16, 2017

DOI: $10.3892 / \mathrm{ol} .2018 .7830$

\begin{abstract}
Gastric cancer is one of the most common cancers globally with high rates of morbidity and mortality. Purified Omphalia lapidescens protein $(\mathrm{pPeOp})$ is a protein extracted from the sclerotium of Omphalia lapidescens. The present study aimed to investigate the effects of $\mathrm{pPe} O \mathrm{p}$ on the viability, migration, cell cycle progression and apoptosis of SGC-7901 cells. The expression of numerous proteins, namely matrix metallopeptidase (MMP)2, MMP9, p53, caspase-3, B-cell lymphoma (Bcl)-2, cyclin A2, cyclin B1, cyclin D1, cyclin dependent kinase (CDK)1, CDK2 and CDK4, were investigated using western blot analysis and reverse transcription-quantitative polymerase chain reaction. The results of the present study demonstrated that treating SGC-7901 cells with $\mathrm{pPe} O \mathrm{p}$ markedly suppressed their migration, induced their apoptosis and arrested their progression in $\mathrm{S}$ phase. $\mathrm{pPe} O \mathrm{p}$ also downregulated the expression of migration-associated proteins (MMP2 and MMP9) and cyclin-associated proteins (cyclin A2, cyclin B1, cyclin D1, CDK1, CDK2 and CDK4) in a dose-dependent manner. Cells treated with pPe $O$ p significantly upregulated caspase-3 and p53 and downregulated $\mathrm{Bcl}-2$. Finally, the impact of $\mathrm{pPeOp}$ on three key nodes of the Janus kinase (JAK)-signal transducer and activator of transcription (STAT) pathway were investigated and it was revealed that expression levels of JAK1, JAK2 and STAT3 were significantly downregulated following treatment.
\end{abstract}

Correspondence to: Professor Yitao Chen, Microbiology and Immunology Laboratory, College of Life Sciences, Zhejiang Chinese Medical University, 548 Binwen Road, Hangzhou, Zhejiang 310053, P.R. China

E-mail: cytworld@zcmu.edu.cn

*Contributed equally

Key words: apoptosis, cell cycle, cell migration, gastric cancer, Omphalia lapidescens proteins
Together, the results of the present study suggested that $\mathrm{pPe} O \mathrm{p}$ suppresses metastasis, arrests cell cycle, induces apoptosis and inhibits the JAK-STAT signaling pathway in SGC-7901 cells. Therefore, $\mathrm{pPe} O \mathrm{p}$ may serve as a novel therapeutic agent for patients with gastric cancer.

\section{Introduction}

Gastric cancer is the second leading cause of cancer-associated mortalities globally and is a major cause of mortality in Asia (1-3). According to a survey in 2015, the mortality rate from gastric cancer ranked second in overall cancer mortality in China (4). Accordingly, therapeutic strategies for treating gastric cancer are in demand.

Surgery and radiotherapy form the mainstay of current therapeutic strategies for localized tumors; however, these treatments are not completely successful and subsequence tumor recurrence and metastases may occur (5). Furthermore, their high cost may be prohibitive and postoperative complications may be severe (6).

Fluorouracil (5-FU) is a classic drug used for gastric cancer treatment (7). It is generally known to exert its antitumor effects by stopping the production of DNA (8). However, numerous cases of drug resistance have been previously reported $(7,8)$. Therefore, alternative treatment options with improved efficacy and fewer side effects are required. For this reason, 5-FU was selected as a positive control for the present study.

In recent years, there has been interest in the application of traditional Chinese medicine for the treatment of tumors (9-11). Proponents claim that 'Lei-Wan', the scientific term for Omphalia lapidescens, possesses medicinal activity against a variety of parasites, including roundworms, spirometra and ancylostomes (12). Numerous studies have sought to elucidate the anti-tumor effects of 'Lei-Wan' and its underlying molecular mechanisms $(13,14)$. Purified Omphalia lapidescens protein $(\mathrm{pPeO})$ is a protein extracted from the sclerotium of Omphalia lapidescens by polyvinyl pyrrolidone (PVP) extraction buffer. In a previous study, it was demonstrated that $\mathrm{pPe} O \mathrm{p}$ promotes apoptosis and cell cycle arrest of tumor cells (MC-4), but did not cause toxicity to normal gastric cells (MC-1) (15). 
Those wishing to study the underlying biology of $\mathrm{pPe} O \mathrm{p}$ would have to study its influence on the intricate network of numerous regulatory molecules that govern tumor genesis.

In the present study, the ability of $\mathrm{pPe} O \mathrm{p}$ to inhibit the migration of SGC-7901 gastric cancer cells was investigated. SGC-7901 cells were treated with different dosages of $\mathrm{pPeOp}$, following which, the extent of apoptosis and cell cycle arrest was determined. Furthermore, the potential underlying mechanism of action of $\mathrm{pPe} O \mathrm{p}$ was investigated by studying the Janus kinase (JAK)-signal transducer and activator of transcription (STAT) signaling pathway and a number of key regulatory molecules [matrix metallopeptidase (MMP)2, MMP9, cyclin D1, cyclin A2, cyclin B1, cyclin dependent kinase (CDK)1, CDK2, CDK4, B-cell lymphoma (Bcl)-2, p53 and caspase-3].

\section{Materials and methods}

pPeOp extraction and purification. The fruiting body of Omphalia lapidescens was provided by Fang Hui Chun Tang (Hangzhou, China). A total of $200 \mathrm{mg}$ of the fruiting body of Omphalia lapidescens was washed three times with distilled water at $4^{\circ} \mathrm{C}$ and placed into $0.875 \mathrm{ml}$ of cold PVP extraction buffer (15\% 1.0 M Tris-HCl, pH 8.0; 2\% PVP; 25\% glycerol) on ice for $4 \mathrm{~h}$. The samples were then centrifuged $(12,000 \mathrm{x} \mathrm{g}$, $20 \mathrm{~min}$ ) at $4^{\circ} \mathrm{C}$, and the supernatant was collected and retained for purification.

A SephadexG-50 column (GE Healthcare Life Sciences, Little Chalfont, UK), pre-equilibrated with $50 \mathrm{mM}$ Tris- $\mathrm{HCl}$ buffer ( $\mathrm{pH} 8.5)$, was employed to purify the sample $(1 \mathrm{ml}$ sample for each experiment). The absorbance was measured at $280 \mathrm{~nm}$, and the flow rate was $0.2 \mathrm{ml} / \mathrm{min}$, producing three peaks. In accordance with a previously described protocol (15), the second $A_{280 \mathrm{~nm}}$ peak fraction was ultrafiltrated using a Millipore ultrafiltration tube (EDM Millipore, Billerica, MA, USA). Finally, the protein was sterilized by filtration using a $0.22 \mu \mathrm{m}$ filter, and then stored at $-20^{\circ} \mathrm{C}$ for later use.

Cell culture. The human gastric cancer cell line SGC-7901 was provided from Zhejiang Provincial Center for Disease Control and Prevention (Zhejiang, China). SGC-7901 cells were cultured in RPMI-1640 medium (cat no. GNM31800; Hangzhou Genom Biomedical Technology Co., Ltd., Hangzhou, China; http://www.genom.com.cn/) supplemented with 5\% (v/v) fetal bovine serum (cat no. 22011-8612; Zhejiang Tianhang Biotechnology Co., Ltd., Zhejiang, China), 100 U/ml penicillin and $100 \mu \mathrm{g} / \mathrm{ml}$ streptomycin at $37^{\circ} \mathrm{C}, 5 \% \mathrm{CO}_{2}$.

Cell viability assay. Cultured SGC-7901 cells were detached with $0.25 \%$ trypsin during the logarithmic growth phase. The suspension of SGC-7901 cells containing $1 \times 10^{6} / \mathrm{ml}$ cells was seeded into a 96 -well plate and incubated at $37^{\circ} \mathrm{C}$ with $5 \%$ $\mathrm{CO}_{2}$ for $24 \mathrm{~h}$ in preparation for an MTS assay. Subsequently, pPe $O \mathrm{p}$ (30, 60 and $90 \mu \mathrm{g} / \mathrm{ml}), 100 \mu \mathrm{g} / \mathrm{ml}$-FU (cat no. 51-21-8; Sigma-Aldrich; Merck KGaA, Darmstadt, Germany) or PVP (90 $\mu \mathrm{g} / \mathrm{ml})$ diluted with RPMI-1640, which had been sterilized through a $0.22 \mu \mathrm{m}$ filter, were added to the cells and incubated for $24 \mathrm{~h}$ at $37^{\circ} \mathrm{C}$. A CellTiter $96^{\circledR}$ AQueous One Solution Assay kit (cat no. G3580; Promega Corporation, Madison, WI, USA) was used for the MTS assay, according to the manufacture protocol. According to the manufacturer's protocol, $20 \mu \mathrm{l}$ MTS solution (Promega Corporation) was added to each well, briefly agitated for $30 \mathrm{sec}$ and incubated at $37^{\circ} \mathrm{C}$ for $60 \mathrm{~min}$. Absorbance at $490 \mathrm{~nm}$ was measured using an automatic microwell plate reader (Thermo Labsystems, Helsinki, Finland). The light microscope used to visualize cells was the Nikon eclipse ti (Nikon Corporation, Tokyo, Japan) at a magnification of $\mathrm{x} 100$.

Cell migration assay. Cellular migration was investigated using a wound-healing assay. SGC-7901 cells $\left(1 \times 10^{6} / \mathrm{ml}\right)$ were seeded into 6 -well plates and cultured under standard aforementioned conditions for $\sim 24 \mathrm{~h}$. When cells were $\sim 80 \%$ confluent, a wound was scratched into the cell layer with a $200 \mu 1$ pipette tip. Cells were then treated with 30,60 or $90 \mu \mathrm{g} / \mathrm{ml} \mathrm{pPeOp}, 90 \mu \mathrm{g} / \mathrm{ml}$ PVP or $100 \mu \mathrm{g} / \mathrm{ml} 5-\mathrm{FU}$; for $24 \mathrm{~h}$ at $37^{\circ} \mathrm{C}$. Cells were then washed with pre-warmed PBS $\left(37^{\circ} \mathrm{C}\right)$ to remove cell debris and allowed to migrate for $24 \mathrm{~h}$ prior to image capture.

Flow cytometry detection of cell cycle. SGC-7901 cells were located in 6-well plates and incubated under standard aforementioned conditions for $24 \mathrm{~h}$ in preparation for a cell cycle assay. Then, cells were treated with pPe $O p$ (30, 60 or $90 \mu \mathrm{g} / \mathrm{ml})$, PVP $(100 \mu \mathrm{g} / \mathrm{ml})$ or 5 -FU $(100 \mu \mathrm{g} / \mathrm{ml})$ under standard aforementioned conditions for $24 \mathrm{~h}$. Cultured cells were harvested with EDTA-free trypsin $(0.25 \%)$ and washed twice with ice-cold PBS. Subsequently, cells $\left(1 \times 10^{6} / \mathrm{ml}\right)$ were incubated with $0.5 \mathrm{ml}$ propidium iodide (PI)/RNase staining buffer (cat no. 550825; BD Biosciences, San Jose, CA, USA) for $15 \mathrm{~min}$ at room temperature $\left(25^{\circ} \mathrm{C}\right)$ in the dark prior to being fixed with $1 \%$ paraformaldehyde (Beijing Solarbio Science \& Technology Co., Ltd., Beijing, China) at $25^{\circ} \mathrm{C}$ for $30 \mathrm{~min}$, and stored in $70 \%$ ethanol at $-20^{\circ} \mathrm{C}$ for $15 \mathrm{~min}$. Cell cycle progression analyses were performed using a Beckman FC500 (Beckman Coulter, Inc., Brea, CA, USA) flow cytometer with red fluorescent light at a wavelength of $488 \mathrm{~nm}$. Win Cycle software (version 32; Beckman Coulter, Inc.) were used for analyses.

Flow cytometry detection of apoptosis. FITC Annexin V Apoptosis Detection kit I (cat no. 556547; BD Biosciences) was used to assay cell apoptosis. Cultured cells, subsequent to treatment with pPeOp $(30,60$ or $90 \mu \mathrm{g} / \mathrm{ml})$, PVP $(100 \mu \mathrm{g} / \mathrm{ml})$ or 5 -FU $(100 \mu \mathrm{g} / \mathrm{ml})$ under standard aforementioned conditions for $24 \mathrm{~h}$, were collected with EDTA-free trypsin $(0.25 \%)$ and washed twice with ice-cold PBS. Subsequently, cells $\left(1 \times 10^{6} / \mathrm{ml}\right)$ were resuspended in $100 \mu 1 \mathrm{X}$ binding buffer solution (BD Biosciences), to which $5 \mu 1$ of fluorescein isothiocyanate/Annexin $\mathrm{V}$ (BD Biosciences) and $5 \mu \mathrm{l}$ PI (BD Biosciences) were added. Cells were then gently vortexed and incubated for $15 \mathrm{~min}$ at room temperature $\left(25^{\circ} \mathrm{C}\right)$ in the dark. Incubated cells were washed again with $1 \mathrm{X}$ binding buffer and resuspended in $200 \mu \mathrm{l}$ of $1 \mathrm{X}$ binding buffer. PI $(5 \mu \mathrm{l})$ and $400 \mu \mathrm{l}$ of $1 \mathrm{X}$ binding buffer were added to each sample, and samples were analyzed using a Beckman FC500 flow cytometer (Beckman Coulter, Inc.). The software used to analyze apoptosis was CXP analysis (version 32; Beckman Coulter, Inc.). 
Reverse transcription-quantitative polymerase chain reaction (RT-qPCR) assay. MMP2, MMP9, cyclin D1, cyclin A2, cyclin B1, CDK1, CDK2, CDK4, Bcl-2, p53, caspase-3, JAK1, JAK2 and STAT3) were analyzed by RT-qPCR. In brief, cells $\left(1 \times 10^{6} / \mathrm{ml}\right)$, subsequent to treatment with $\mathrm{pPe} O \mathrm{p}$ $(30,60$ or $90 \mu \mathrm{g} / \mathrm{ml})$, PVP $(100 \mu \mathrm{g} / \mathrm{ml})$ or $5-\mathrm{FU}(100 \mu \mathrm{g} / \mathrm{ml})$ under standard aforementioned conditions for $24 \mathrm{~h}$, were trypsinized and total RNA was isolated using TRIzol reagent (Invitrogen; Thermo Fisher Scientific, Inc., Waltham, MA, USA). cDNA was synthesized using a Maxima First Strand cDNA Synthesis kit (Thermo Fisher Scientific, Inc.), according to the manufacturer's protocol, which was used as a template for qPCR. Taq ${ }^{\circledR}$ PCR Master Mix (cat no. A6001; Promega Corporation) for qPCR, and performed using a Step One Plus Real-Time PCR System (Applied Biosystems; Thermo Fisher Scientific, Inc.), according to the manufacturer's protocol. Data were normalized to the expression level of a GAPDH reference gene. Fold-changes in the amplified cDNA were calculated by the $\left(2^{-\Delta \Delta C q}\right)$ method (16). Primer sequences used are presented in Table I. All primers were purchased from Sangon Biotech Co., Ltd. (Shanghai, China). RT-qPCR was performed using an Eppendorf Realplex-4 Real Time PCR Machine (Eppendorf, Hamburg, Germany). The PCR amplification conditions were as follows: One cycle at $95^{\circ} \mathrm{C}$ pre-denaturing for $2 \mathrm{~min}$, followed by 40 cycles at $95^{\circ} \mathrm{C}$ denaturing for $15 \mathrm{sec}$, and annealing temperature of $62.9^{\circ} \mathrm{C}$ (GAPDH, JAK1, JAK2, STAT3, caspase-3, p53, Bcl-2), $57.8^{\circ} \mathrm{C}$ (MMP2, MMP9, cyclin A2, cyclin B1, cyclin D1) or $61^{\circ} \mathrm{C}$ (CDK1, CDK2, CDK4) for $1 \mathrm{~min}$. At the end of the PCR cycle, a dissociation curve was performed with StepOne ${ }^{\mathrm{TM}}$ Software (version 2.2.2; Applied Biosystems; Thermo Fisher Scientific, Inc.) to confirm amplification of a single product. The results are represented as the fold-change in gene expression relative to GAPDH.

Western blotting assay. MMP2, MMP9, cyclin D1, cyclin A2, cyclin B1, CDK1, CDK2, CDK4, Bcl-2, p53, caspase-3, JAK1, JAK2 and STAT3 were analyzed by western blot analysis. Cells $\left(1 \times 10^{6}\right)$, subsequent to treatment with $\mathrm{pPe} O \mathrm{p}(30,60$ or $90 \mu \mathrm{g} / \mathrm{ml})$, PVP $(100 \mu \mathrm{g} / \mathrm{ml})$ or $5-\mathrm{FU}(100 \mu \mathrm{g} / \mathrm{ml})$ under standard aforementioned conditions for $24 \mathrm{~h}$, were collected following treatment with PBS $(1 \mathrm{ml}, 30 \mathrm{~min})$; centrifuged for $10 \mathrm{~min}$ at $200 \mathrm{x} \mathrm{g}$ and the supernatant was discarded. The pellet was then incubated with $200 \mu \mathrm{l}$ lysis buffer (cat no. C0201; Beyotime Institute of Biotechnology, Shanghai, China) for $30 \mathrm{~min}$ on ice, and agitated every $10 \mathrm{sec}$. Lysates were separated using centrifugation at $4^{\circ} \mathrm{C}$ for $15 \mathrm{~min}$ at $10,000 \times \mathrm{g}$, the supernatant was collected, and protein determined by BCA Protein Assay kit (cat no. KGP902; Nanjing KeyGen Biotech Co., Ltd., Nanjing, China). Protein (40 $\mu \mathrm{g}$ per lane) was loaded onto a $12 \%$ standard polyacrylamide gel and resolved by SDS-PAGE. Resolved proteins were subsequently transferred onto an Immobilon ${ }^{\circledR}$-P Transfer Membrane (cat no. IPVH00010; Merck KGaA), saturated with $5 \%$ milk in Tris-buffered saline and 0.5\% Tween-20 (TBST) at $25^{\circ} \mathrm{C}$ for $2 \mathrm{~h}$. Antibodies against JAK1 (cat no. ab138005; 1:1,000 dilution), JAK2 (cat no. ab32101; 1:1,000 dilutions) and STAT3 (cat no. ab76315; 1:200,000 dilutions) were purchased from Abcam (Cambridge, UK). Antibodies against MMP2 (cat no. 13132; 1:1,000 dilutions), MMP9 (cat no. 3852;
1:1,000 dilutions), cyclin A2 (cat no. 4656; 1:2,000 dilutions), cyclin B1 (cat no. 4138; 1:1,000 dilutions), cyclin D1 (cat no. 2978; 1:1,000 dilutions), CDK1 (cat no. ab32384; 1:1,000 dilutions), CDK2 (cat no. 2546; 1:1,000 dilutions), CDK4 (cat no. $12790 ; 1: 1,000$ dilutions), Bcl-2 (cat no. $2870 ; 1: 1,000$ dilutions), p53 (cat no. 2527; 1:1,000 dilutions) and caspase-3 (cat no. 14220; 1:1,000 dilutions) were purchased from Cell Signaling Technology, Inc. (Danvers, MA, USA). Anti-GAPDH (cat no. YM3029; 1:5,000 dilutions), used as a control, was purchased from Immuno Way Biotechnology Company (TX, USA). Horseradish peroxidase (HRP)-conjugated goat anti-rabbit immunoglobulin G (cat no. A0208; 1:1,000 dilutions) or goat anti-mouse immunoglobulin G (cat no. A0216;1: 1,000 dilutions) were used as secondary antibodies. All secondary antibodies were purchased from the Beyotime Institute of Biotechnology. The membranes were incubated overnight with primary antibodies (described above) at $4^{\circ} \mathrm{C}$. Membranes were washed three times with TBST. Membranes that were incubated with GAPDH antibodies were then incubated with goat anti-mouse IgG secondary antibody (described above), while membranes which were incubated with MMP2, MMP9, cyclin D1, cyclin A2, cyclin B1, CDK1, CDK2, CDK4, Bcl-2, p53, caspase-3, JAK1, JAK2 and STAT3 antibodies were then incubated with goat anti-rabbit IgG HRP secondary antibodies (described above) for $2 \mathrm{~h}$ at $4^{\circ} \mathrm{C}$, and washed three times with TBST. Membranes were visualized on film in a dark room using ECL substrate solution (cat no. P0018A; Beyotime Institute of Biotechnology) and results quantified using ImageJ software (version 1.8.0; National Institutes of Health, Bethesda, MA, USA).

Statistical analyses. All experiments were conducted in triplicate. Data are presented as the mean \pm standard deviation. SPSS software (version 20.0; IBM Corp., Armonk, NY, USA) was used for statistical analyses. The MTS cell viability data were subjected to one-way analysis of variance (ANOVA), followed by Fisher's least significant difference (LSD) post-hoc test. Flow cytometry-based analyses were also analyzed using one-way ANOVA, followed by Fisher's LSD. Western blot results were quantitated using Image J software and analyzed by one-way ANOVA, followed by Fisher's LSD. $\mathrm{P}<0.05$ was considered to indicate a statistically significant difference.

\section{Results}

Effect of pPeOp on the viability of SGC-7901 cells. Initially, the effect of $\mathrm{pPe} O \mathrm{p}$ on the proliferation of SGC-7901 gastric cancer cells was investigated. Cells treated with PVP $(90 \mu \mathrm{g} / \mathrm{ml}, 24 \mathrm{~h})$ maintained a normal morphology comparable to that of untreated cells (Fig. 1). However, when SGC-7901 cells were treated for $24 \mathrm{~h}$ with graded concentrations of $\mathrm{pPe} O \mathrm{p}(30,60$ and $90 \mu \mathrm{g} / \mathrm{ml})$, cells decreased in size and presented a spherical appearance (Fig. 1A). In addition to the morphological changes, the viability was also affected. The survival rates of cells after $24 \mathrm{~h}$ of treatment were as follows: PVP $(100 \mu \mathrm{g} / \mathrm{ml}), 95.26 \pm 5.21 \%$; 5-FU (100 $\mu \mathrm{g} / \mathrm{ml}), 60.13 \pm 3.13 \%$; pPeOp $(30 \mu \mathrm{g} / \mathrm{ml}), 70.97 \pm 6.18 \%$; pPe $O \mathrm{p}(60 \mu \mathrm{g} / \mathrm{ml}), 58.44 \pm 5.74 \% ; \mathrm{pPe} O \mathrm{p}(90 \mu \mathrm{g} / \mathrm{ml})$ $35.22 \pm 2.33 \%$. The half maximal inhibitory concentration was $64.326 \mu \mathrm{g} / \mathrm{ml}$. An increase in the concentration of $\mathrm{pPe} O \mathrm{p}$ 
Table I. Specific primers used for polymerase chain reaction analysis.

\begin{tabular}{lllr}
\hline Gene & \multicolumn{1}{c}{ Forward primer, 5'-3' } & \multicolumn{1}{c}{ Reverse primer, 5'-3' } & Ampl \\
\hline GAPDH & TGACTTCAACAGCGACACCCA & CACCCTGTTGCTGTAGCCAAA & 121 \\
CDK1 & TGCTGGGGTCAGCTCGTTACTCA & TGGGATGCTAGGCTTCCTGGTT & 326 \\
CDK2 & GTGGGCCCGGCAAGATTTAG & GCCGAAATCCGCTTGTTAGGG & 378 \\
CDK4 & CTTGATCTGAGAATGGCTACCTCT & CATGAAGGAAATCTAGGCCTCTTA & 682 \\
Cyclin D1 & CATCTCTGTACTTTGCTTGCTCAT & CGCTATTTCCACACCTATTGGAC & 499 \\
Cyclin B1 & TCGAGCAACATACTTTGG & GCAAAAAGCTCCTGCTGC & 101 \\
Cyclin A2 & AGACCCTGCATTTGGCTGTG & ACAAACTCTGCTACTTCTGG & 1,110 \\
MMP2 & TGATGGTGTCTGCTGGAAAG & GACACGTGAAAAGTGCCTTG & 280 \\
MMP9 & GGAGACCTGAGAACCAATCTC & TCCAATAGGTGATGTTGTGG & 1,078 \\
Caspase-3 & CATGGAAGCGAATCAATGGACT & CTGTACCAGACCGAGATGTCA & 3,036 \\
p53 & TAGTGTGGTGGTGCCCTATG & CCAGTGTGATGATGGTGAGG & 699 \\
JAK1 & CCTGCTGGTGGCTACTAAGA & AGATGTGTGTTCTCGTGCCT & 3,262 \\
JAK2 & GCCTTCTTTCAGAGCCATCA & CCAGGGCACCTATCCTCATA & 1,148 \\
STAT3 & GACATGGAGTTGACCTCGGAGTG & GGTGGCAGAATGCAGGTAGGC & 103 \\
Bcl-2 & GGATTGTGGCCTTCTTTGAG & CCAAACTGAGCAGAGTCTTC & 234 \\
\hline
\end{tabular}

Ampl, amplification; CDK, cyclin dependent kinase; MMP, matrix metallopeptidase; JAK, Janus kinase; STAT, signal transducer and activator of transcription; Bcl, B-cell lymphoma.

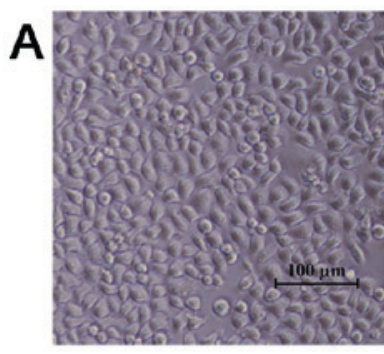

Normal

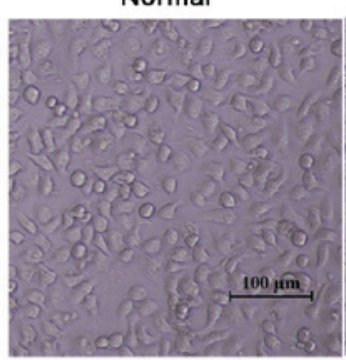

$30 \mu \mathrm{g} / \mathrm{ml} \mathrm{pPeOp}$

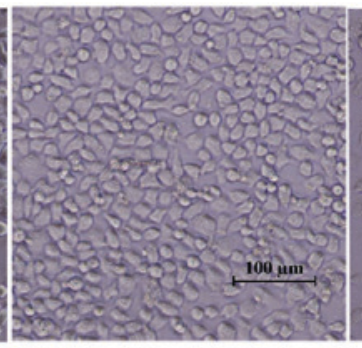

$90 \mu \mathrm{g} / \mathrm{ml} \mathrm{PVP}$

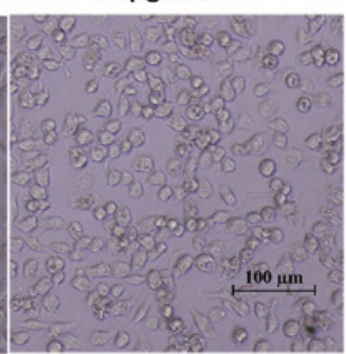

$60 \mu \mathrm{g} / \mathrm{ml} \mathrm{pPeOp}$

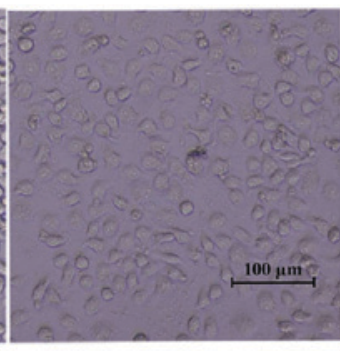

$100 \mu \mathrm{g} / \mathrm{ml} 5-\mathrm{Fu}$

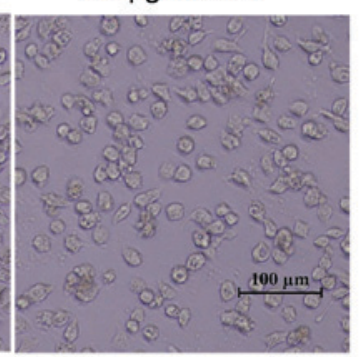

$90 \mu \mathrm{g} / \mathrm{ml} \mathrm{pPeOp}$

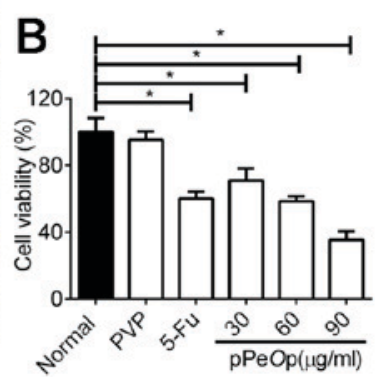

Figure 1. pPe $O$ p decreases viability of SGC-7901 cells. (A) SGC-7901 cells treated with 30,60 or $90 \mu \mathrm{g} / \mathrm{ml} \mathrm{pPe} O \mathrm{p}, 90 \mu \mathrm{g} / \mathrm{ml} \mathrm{PVP}$ or $100 \mu \mathrm{g} / \mathrm{ml} 5-\mathrm{FU}$ for $24 \mathrm{~h}$, and visualized by light microscopy. (B) Cell viability rates analyzed by MTS assay. Data were normalized to the Normal group. "P $<0.05$ vs. Normal control. pPeOp, purified Omphalia lapidescens protein; PVP, polyvinyl pyrrolidone; 5-FU, 5-fluorouracil.

resulted in a proportional and significant increase in the rate of inhibition $(\mathrm{P}<0.05$; Fig. 1B). These results suggested that $\mathrm{pPe} O \mathrm{p}$ inhibits the viability of SGC-7901 cells.

Effect of pPeOp on the migration of SGC-7901 cells. A wound healing assay was used to assess the migration ability of SGC-7901 cells following treatment with $\mathrm{pPeO}$ p. As presented in Fig. 2A, compared with the normal and negative normal treatments, the migration ability of SGC-7901 cells was markedly decreased following $\mathrm{pPe} O \mathrm{p}$ treatment.
Invasion and metastasis of carcinomas are closely associated with extracellular matrix (ECM) degradation $(17,18)$. MMPs are well characterized and demonstrate proteolytic activity in the ECM, and have recently emerged as key molecules involved in mediating tumor invasion and metastasis (19). Therefore, MMP2 and MMP9 were selected for further studies. MMP2 and MMP9 levels were evaluated by RT-qPCR and western blot analysis. The results demonstrated that MMP2 and MMP9 were significantly downregulated at the mRNA and protein levels compared with the normal control, 
A

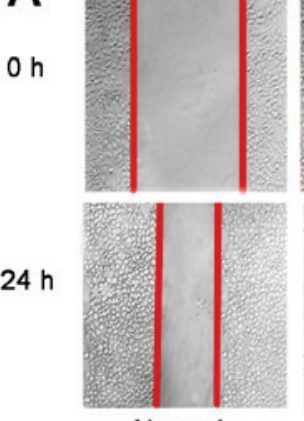

Normal

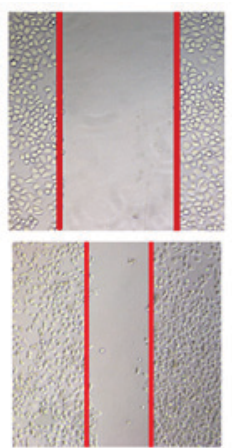

$90 \mu \mathrm{g} / \mathrm{ml}$ PVP

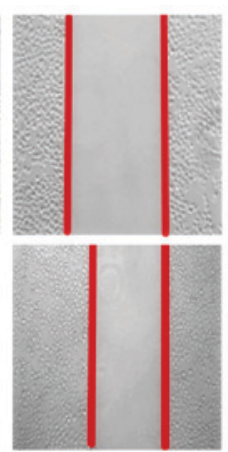

$100 \mu \mathrm{g} / \mathrm{ml} 5-\mathrm{Fu}$
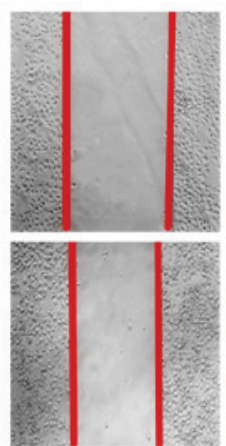

$30 \mu \mathrm{g} / \mathrm{ml} \mathrm{pPeOp}$
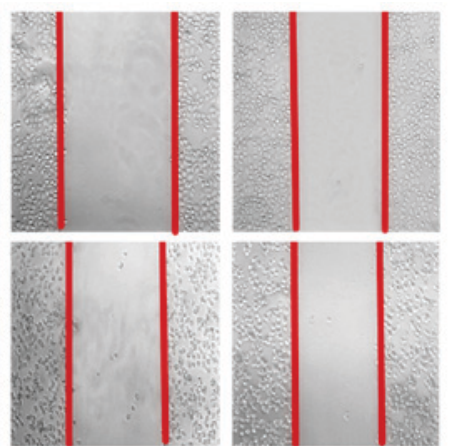

$60 \mu \mathrm{g} / \mathrm{ml} \mathrm{pPeOp} 90 \mu \mathrm{g} / \mathrm{ml} \mathrm{pPeOp}$

B

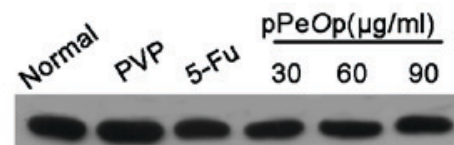

MMP2

MMP9
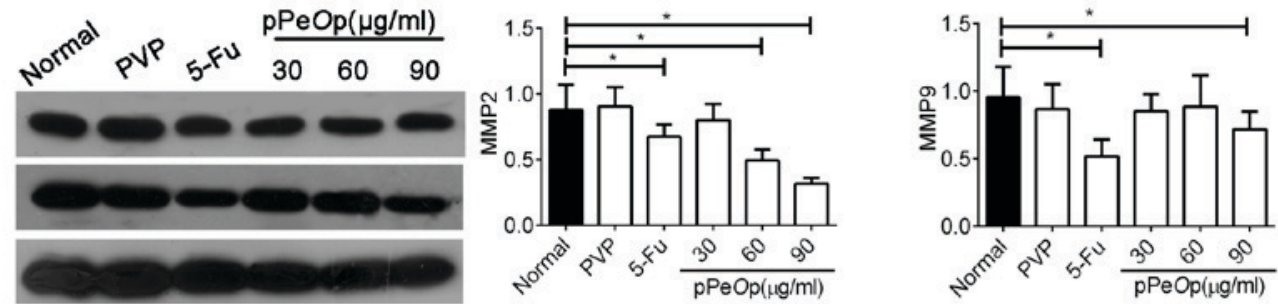

GAPDH

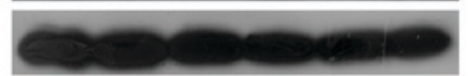

C
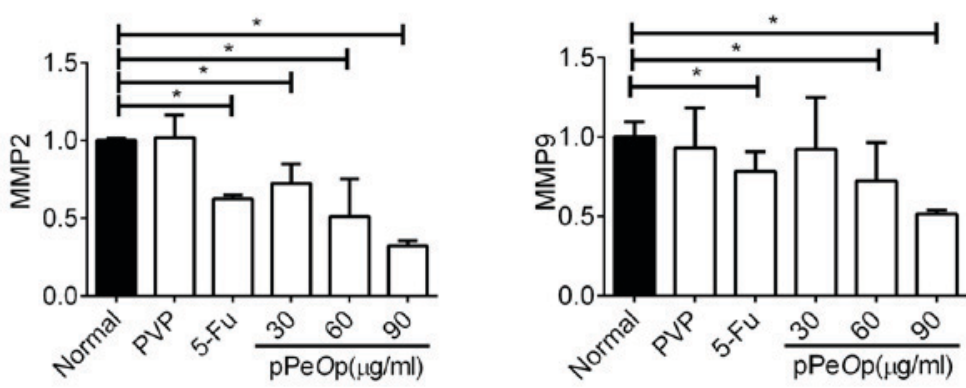

Figure 2. pPeOp inhibits SGC-7901 cell migration. SGC-7901 cells were treated with 30, 60 or $90 \mu \mathrm{g} / \mathrm{ml} \mathrm{pPe} O \mathrm{p}, 90 \mu \mathrm{g} / \mathrm{ml} \mathrm{PVP}$ or $100 \mu \mathrm{g} / \mathrm{ml} 5$-FU for $24 \mathrm{~h}$. (A) Effects of pPeOp on SGC-7901 cells using a wound healing assay. (B) Effects of pPeOp on the expression of the migration-associated proteins MMP2 and MMP9, using GAPDH as loading control. (C) Reverse transcription-quantitative polymerase chain reaction was used to assess cell migration-associated factors expression levels in SGC-7901 cells. All data were normalized to the Normal group. ${ }^{*} \mathrm{P}<0.05$ vs. Normal control. pPeOp, purified Omphalia lapidescens protein; PVP, polyvinyl pyrrolidone; 5-FU, 5-fluorouracil; MMP, matrix metallopeptidase.

in proportion to the $\mathrm{pPe} O \mathrm{p}$ dosage $(\mathrm{P}<0.05$; Fig. $2 \mathrm{~B}$ and $\mathrm{C})$. However, compared with the normal group, cells treated with PVP did not show any significant difference in gene or protein expression profiles ( $\mathrm{P}>0.05$; Fig. $2 \mathrm{~B}$ and $\mathrm{C}$ ). Thus, the results suggest that $\mathrm{pPe} O \mathrm{p}$ inhibits the ability of SGC-7901 cells to migrate.

Effect of pPeOp on the cell cycle progression of SGC-7901 cells. The influence $\mathrm{pPe} O \mathrm{p}$ has on the progression of SGC-7901 cells through the cell cycle was investigated using flow cytometry of cells post-treatment with either normal/5-FU/PVP or graded concentrations of $\mathrm{pPeOp}$ (Fig. 3A). The percentage of cells in $\mathrm{G} 2 / \mathrm{M}$ phases decreased, whereas the proportion of cells in $\mathrm{G} 0 / \mathrm{G} 1, \mathrm{~S}$ phases increased in the $\mathrm{pPe} O \mathrm{p}$-treated group compared with the control $(\mathrm{P}<0.05$, Fig. $3 \mathrm{~A})$. This suggests that $\mathrm{pPe} O \mathrm{p}$ blocks DNA replication, thereby arresting cells in the $\mathrm{S}$ phase.

To verify the data obtained by flow cytometry, how $\mathrm{pPe} O \mathrm{p}$ treatment influenced the expression of several cell cycle regulators, including cyclin A2, cyclin B1, cyclin D1, CDK1, CDK2, and CDK4 was investigated using RT-qPCR and western blot analysis. The results indicated that protein and mRNA expression levels of all six genes were significantly decreased post-treatment with $\mathrm{pPe} O \mathrm{p}$ compared with the normal control $(\mathrm{P}<0.05$; Fig. 3B and $\mathrm{C})$. Furthermore, no significant differences were observed between untreated cells and cells treated with PVP ( $>>0.05$; Fig. 3B and C). Collectively, these results suggest that $\mathrm{pPeO}$ p arrests cell cycle progression of SGC-7901 cells.

Effect of pPeOp on the apoptosis of SGC-7901 cells. Flow cytometry was used to investigate how treatment with normal/5-FU/PVP or varying dosages of $\mathrm{pPeOp}$ affects the proportions of SGC-7901 cells undergoing apoptosis (Fig. 4A). The results demonstrated that $\mathrm{pPeOp}$ treatment induced SGC-7901 cancer cells to undergo apoptosis in a dose-dependent manner. Cells treated with 5-FU $(100 \mu \mathrm{g} / \mathrm{ml}$ for $24 \mathrm{~h}$ ) demonstrated a high rate of apoptosis (21\%; Fig. 4A). In addition, cells treated with pPe $O \mathrm{p}(90 \mu \mathrm{g} / \mathrm{ml}$ for $24 \mathrm{~h})$ experienced a markedly increased rate of apoptosis $(35.1 \%$; Fig. 4A), surpassing that of 5-FU treatment.

Subsequently, the molecular events underlying this modulation in apoptosis were investigated by determining the expression of apoptosis-associated factors, namely caspase-3, p53 and $\mathrm{Bcl}-2$, at the mRNA and protein levels. The results indicated that $\mathrm{pPe} O \mathrm{p}$ significantly upregulated the 

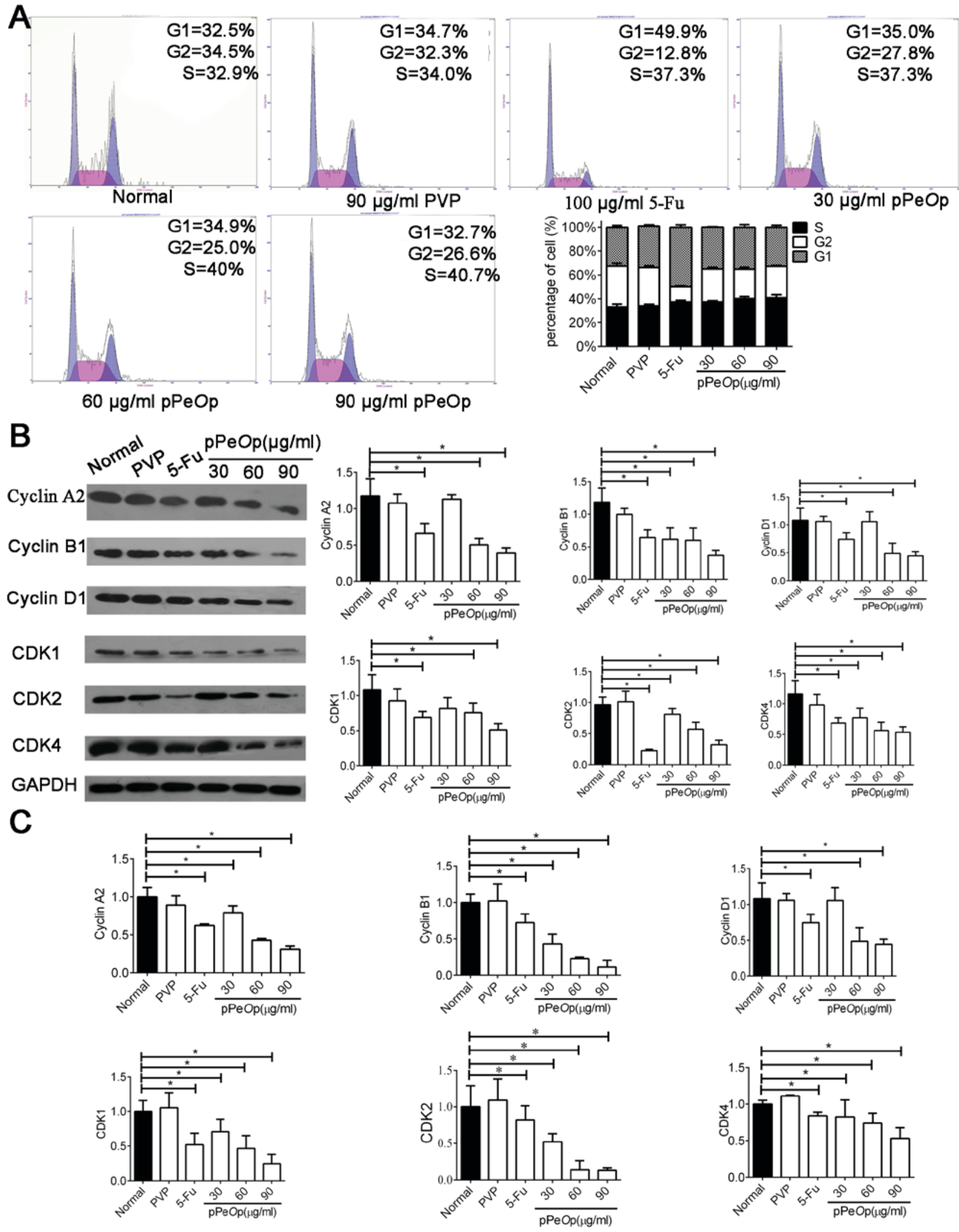

Figure 3. pPe $O \mathrm{p}$ arrest SGC-7901 cell cycle in the S phase. (A) SGC-7901 cells were treated with 30,60 or $90 \mu \mathrm{g} / \mathrm{ml} \mathrm{pPe} O \mathrm{p}, 90 \mu \mathrm{g} / \mathrm{ml} \mathrm{PVP} \mathrm{or} 100 \mu \mathrm{g} / \mathrm{ml} 5-\mathrm{FU}$ for $24 \mathrm{~h}$ and analyzed by flow cytometry. The bar graph summarizes the percentage of cells per cell cycle. (B) Western blot analysis was used to assess cell cycle-associated protein expression levels. All data were normalized to the Normal group. (C) Quantification of cycle-associated mRNA levels normalized to GAPDH. Values are presented as the mean \pm standard deviation of at least three independent experiments. ${ }^{*} \mathrm{P}<0.05$ vs. Normal control. pPe $O$ p, purified Omphalia lapidescens protein; PVP, polyvinyl pyrrolidone; 5-FU, 5-fluorouracil; CDK, cyclin dependent kinase.

expression of caspase- 3 and $\mathrm{p} 53$, and markedly downregulated the expression of $\mathrm{Bcl}-2$ ( $\mathrm{P}<0.05$; Fig. 4B and $\mathrm{C})$. There was no significant difference in the expression of these regulators between normal and PVP-treated cells ( $\mathrm{P}>0.05$; Fig. 4B and C). 

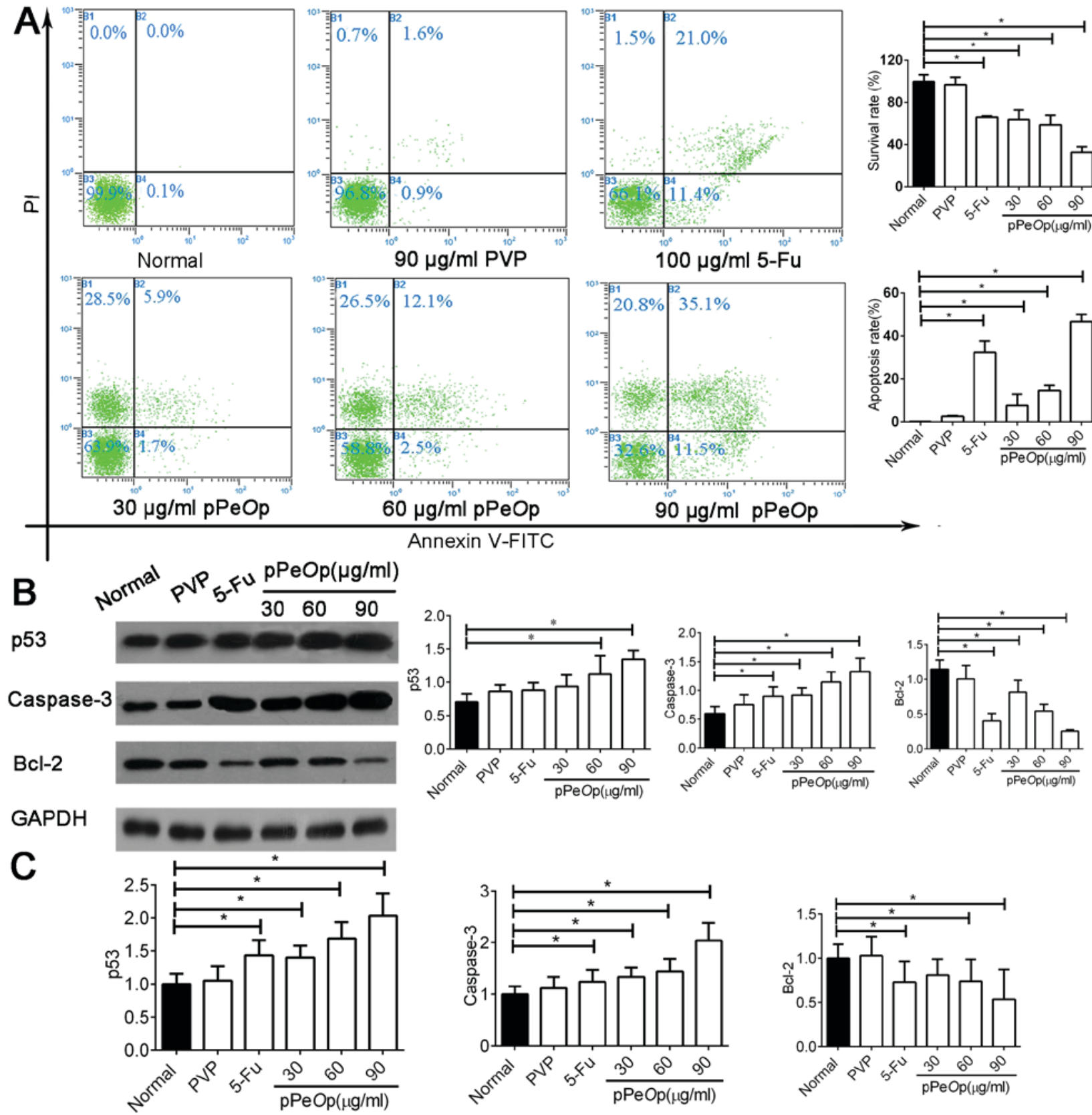

Figure 4. pPeOp induced SGC-7901 cell apoptosis. (A) SGC-7901 cells treated with 30,60, $90 \mu \mathrm{g} / \mathrm{ml} \mathrm{pPe} O \mathrm{p}, 90 \mu \mathrm{g} / \mathrm{ml} \mathrm{PVP}$ or $100 \mu \mathrm{g} / \mathrm{ml} 5-\mathrm{FU}$ for $24 \mathrm{~h}$ and analyzed using flow cytometry. Values are presented as the mean \pm standard deviation from at least three independent experiments performed in triplicate. (B) Western blot analysis was used to assess cell apoptosis-associated expression levels in SGC-7901 cells. (C) Reverse transcription-quantitative polymerase chain reaction was used to assess apoptosis-associated expression levels in SGC-7901 cells. All data were normalized to the Normal Group. Quantification of cycle-associated proteins and mRNA levels were normalized to GAPDH. "P<0.05 vs. Normal control. pPeOp, purified Omphalia lapidescens protein; PVP, polyvinyl pyrrolidone; 5-FU, fluorouracil; PI, propidium iodide; FITC, fluorescein isothiocyanate; Bcl, B-cell lymphoma.

These results collectively demonstrate that $\mathrm{pPe} O \mathrm{p}$ is effective for inducing SGC-7901 cells to apoptosis, superseding even a conventional chemotherapeutic agent.

Effect of pPeOp on the JAK-STAT pathway. The aforementioned experiments highlight the effects that $\mathrm{pPe} O \mathrm{p}$ exhibits on a variety of important biological programs, including cell proliferation, migration, apoptosis and cell cycle progression. However, the mechanism underlying these effects remains poorly understood. According to the results of a microarray assay, numerous differentially expressed genes were detected (data not shown). Following Kyoto Encyclopedia of Genes and Genomes analysis, the JAK-STAT signaling pathway was the most notable regulated signaling pathway influenced by $\mathrm{pPe} O \mathrm{p}$ proteins (data not shown). Therefore, it was hypothesized that $\mathrm{pPeO}$ p may exert its anti-tumor effects through its inhibition of the JAK-STAT signaling pathway in SGC-7901 human gastric cells.

In order to investigate this hypothesis, SGC-7901 cells were treated with different concentrations of $\mathrm{pPe} O \mathrm{p}$ for $24 \mathrm{~h}$ and the expression of JAK1, JAK2 and STAT3 mRNA and proteins were explored using RT-qPCR and western blotting. The results demonstrated that the expression of JAK1, JAK2 and STAT3 mRNAs and proteins were 


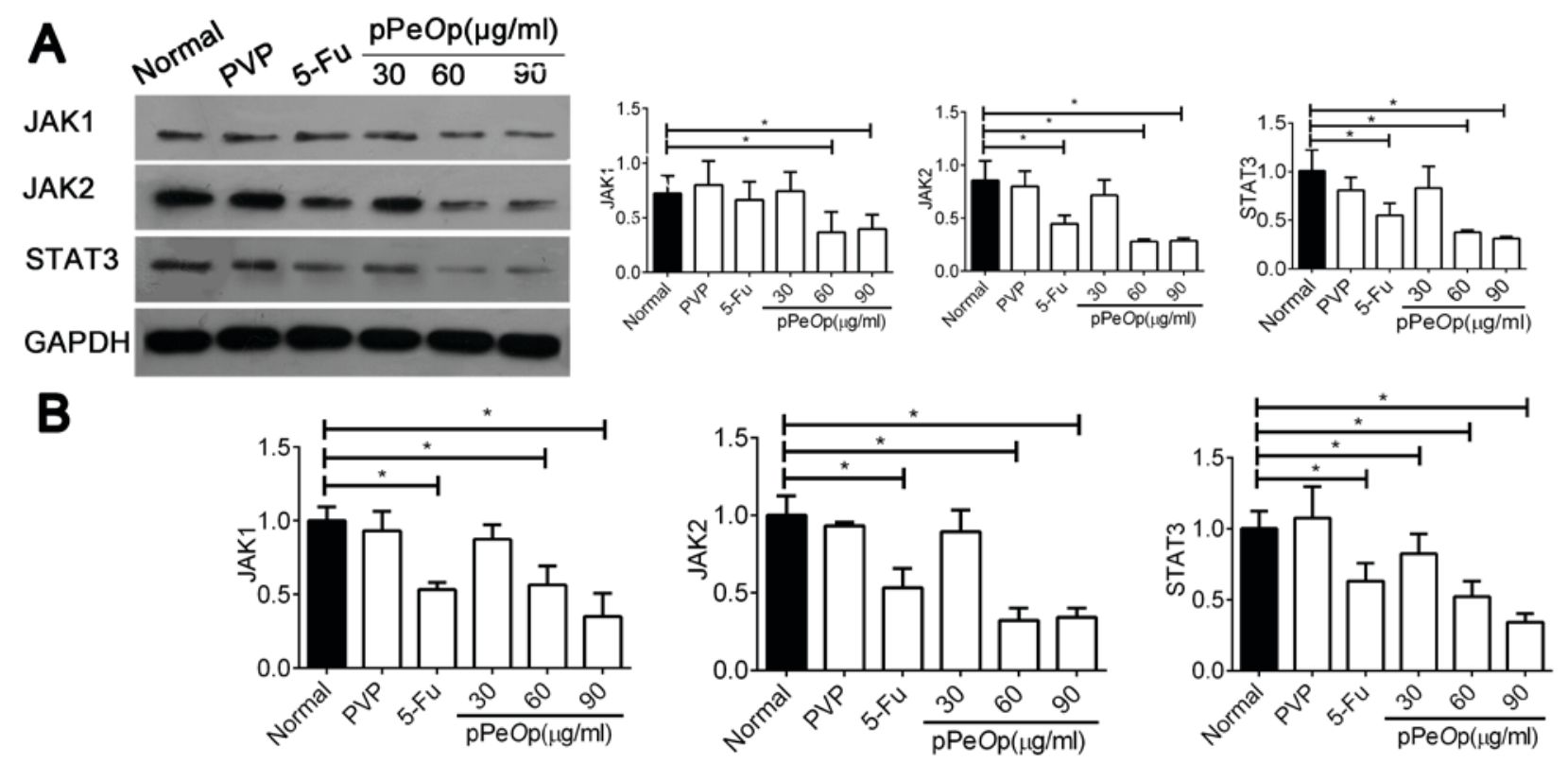

Figure 5.pPeOp inhibited the JAK-STAT3 signaling pathway in SGC-7901 cells. (A) SGC-7901 cells treated with 30,60 and $90 \mu$ g/ml pPe $O$ p, $90 \mu$ g/ml PVP or $100 \mu \mathrm{g} / \mathrm{ml} 5$-FU for $24 \mathrm{~h}$, data is presented as the mean \pm standard deviation for at least three independent experiments. Western blot analysis was used to assess JAK1, JAK2 and STAT3 expression levels in SGC-7901 cells. (B) Reverse transcription-quantitative polymerase chain reaction was performed to evaluate JAK1, JAK2 and STAT3 expression levels in SGC-7901 cells. Data were normalized to the Normal group. Quantification of mRNA levels was normalized to GAPDH. * $\mathrm{P}<0.05$ vs. Normal control. pPeOp, purified Omphalia lapidescens protein; PVP, polyvinyl pyrrolidone; 5-FU, fluorouracil; JAK, Janus kinase; STAT, signal transducer and activator of transcription.

significantly decreased post-treatment with 60 and $90 \mu \mathrm{g} / \mathrm{ml}$ $\mathrm{pPe} O \mathrm{p}$, compared with the control $(\mathrm{P}<0.05$; Fig. $5 \mathrm{~A}$ and $\mathrm{B})$. These results provide evidence for the anti-tumor effects of $\mathrm{pPe} O \mathrm{p}$ being attributed to the inhibition of JAK-STAT signaling.

\section{Discussion}

Metastasis, the dissemination of cancer cells from the primary site to distant sites, is the primary contributor to the mortality of patients with cancer $(20,21)$. The ECM, which serves as a barrier for cell invasion, is breached by MMPs in the evolution process of tumor metastasis (22). MMP9 and MMP2 have been reported to be involved in cancer metastasis due to their ability to degrade type IV collagen, a major component of the basement membrane (23). In the present study, the migration ability of SGC-7901 cells was significantly decreased, whereas MMP2 and MMP9 were significantly downregulated at the mRNA and protein levels in relation to the $\mathrm{pPe} O \mathrm{p}$ dosage, compared with the control group.

Dysregulation of cell cycle control is a major hallmark underlying tumor growth and metastasis $(24,25)$. Cyclins are a family of regulators that control the progression of the cell cycle through the activation of different CDKs. Cyclin D1, cyclin A2 and cyclin B1 facilitate the cell's progression through G0/G1, S and G2/M phases, respectively (26-28). In the present study, $\mathrm{pPe} O \mathrm{p}$ was demonstrated to arrest the cell cycle in the $\mathrm{S}$ phase, and expression levels of cyclin A2, cyclin B1, cyclin D1, CDK1, CDK2 and CDK4 were all decreased in SGC-7901 cells, compared with control group.

Apoptosis is an adenosine 5'triphosphate-dependent and strictly regulated program, in which cells commit themselves to physiological suicide (29). Accordingly, apoptosis is essential for the elimination of excess, redundant and otherwise unhealthy cells in the maintenance of tissue homeostasis and stabilization $(30,31)$. A number of studies have reported that p53, which is described as a 'tumor suppressor', regulates a variety of apoptotic signals in SGC-7901 cell $(32,33)$. Bcl-2, an anti-apoptosis molecule, serves a critical function in controlling apoptosis (34). Caspase-3, classified as an executioner, mediates the final process of cell death (35). In the present study, $\mathrm{pPe} O \mathrm{p}$ treatment induced SGC-7901 cancer cells to undergo apoptosis in a dose-dependent manner. Furthermore, the expression level of p53 and caspase-3 were significantly upregulated, and Bcl-2 were significantly downregulated, in SGC-7901 cells. In addition, the apoptosis rate of SGC-7901 cells that were treated with $90 \mu \mathrm{g} / \mathrm{ml} \mathrm{pPeOp}$ group was increased compared with cells that were treated with $100 \mu \mathrm{g} / \mathrm{ml}$ of the conventional chemotherapeutic agent 5-FU.

The JAK-STAT signaling pathway is abnormally activated in gastric carcinoma, in which regulated gene expression is involved in cell proliferation, cell cycle, invasion, metastasis and survival (36-38). A constitutively active JAK-STAT signaling pathway has been revealed to prevent apoptosis by upregulating the expression of anti-apoptosis proteins, including $\mathrm{Bcl}-2$, Bcl-extra-large, myeloid cell leukemia 1 and surviving (39-41). In addition, JAK-STAT has been demonstrated to accelerate cell cycle progression by enhancing the activity of cyclins $(42,43)$. Masuda et al (44) and Sinibaldi et al (45) reported that inappropriate activation of STAT3 may increase expression of cyclin D1 and subsequently affect cell cycle progression. A number of studies have demonstrated that the expression of activated STAT3 modulated metastasis of tumor cells by promoting gene transcription of MMP2 and MMP9 $(46,47)$. Therefore, inhibition of JAK-STAT is a promising strategy for cancer therapy. In 
the present study, levels of JAK1, JAK2, and STAT3 were significantly decreased at mRNA and protein levels.

The results of the present study suggest that $\mathrm{pPe} O \mathrm{p}$ suppresses metastasis, arrests the cell cycle, induces apoptosis and inhibits JAK-STAT signaling in SGC-7901 cells. Therefore, $\mathrm{pPe} O \mathrm{p}$ may be a promising agent for the treatment of gastric cancer.

\section{Acknowledgements}

The present study was supported by grants from the National Natural Science Foundation Project (grant no. 81374023), the Zhejiang Provincial Natural Science Foundation (grant no. Y207765) and the Zhejiang Provincial Medical and Health Science and Technology Project (grant nos. 2015KYA038 and 2016KYA033).

\section{References}

1. Siegel RL, Miller KD and Jemal A: Cancer statistics, 2017. CA Cancer J Clin 67: 7-30, 2017.

2. Han P, Wang QL and Zhang X: Expression of TRAP1 in gastric cancer tissue and its correlation with malignant biology. Asian Pac J Trop Med 9: 67-71, 2016.

3. Choi HJ, Ki CS, Suh SP and Kim JW: Presymptomatic identification of $\mathrm{CDH} 1$ germline mutation in a healthy korean individual with family history of gastric cancer. Ann Lab Med 34: 386-389, 2014.

4. Chen W, Zheng R, Baade PD, Zhang S, Zeng H, Bray F, Jemal A, $\mathrm{Yu}$ XQ and He J: Cancer statistics in China, 2015. CA Cancer J Clin 66: 115-132, 2016.

5. Ma B, Xu Q, Song Y, Gao P and Wang Z: Current issues of preoperative radio(chemo)therapy and its future evolution in locally advanced rectal cancer. Future Oncol 13: 2489-2501, 2017.

6. Robertson-Tessi M, Gillies RJ, Gatenby RA and Anderson AR: Impact of metabolic heterogeneity on tumor growth, invasion, and treatment outcomes. Cancer Res 75: 1567-1579, 2015.

7. Ben Nasr S, Ayadi M, Bahloul R, Guesmi S, Allani B, Chrait N, Rifi H, Rais $\mathrm{H}$ and Mezlini A: Perioperative chemotherapy in locally advanced gastric cancer. A retrospective study about 25 cases. Tunis Med 93: 228-230, 2015.

8. Peters GJ, Backus HH, Freemantle S, van Triest B, Codacci-Pisanelli G, van der Wilt CL, Smid K, Lunec J, Calvert AH, Marsh S, et al: Induction of thymidylate synthase as a 5-fluorouracil resistance mechanism. Biochim Biophys Acta 1587: 194-205, 2002.

9. Meng H, Peng N, Yu M, Sun X, Ma Y, Yang G and Wang X: Treatment of triple-negative breast cancer with Chinese herbal medicine: A prospective cohort study protocol. Medicine (Baltimore) 96: e8408, 2017.

10. Tsai YT, Lai JN, Lo PC, Chen CN and Lin JG: Prescription of Chinese herbal products is associated with a decreased risk of invasive breast cancer. Medicine (Baltimore) 96: e7918, 2017.

11. Zhang Y, Liang Y and He C: Anticancer activities and mechanisms of heat-clearing and detoxicating traditional Chinese herbal medicine. Chin Med 12: 20, 2017.

12. Rashid N, Koh HA, Baca HC, Lin KJ, Malecha SE and Masaquel A: Economic burden related to chemotherapy-related adverse events in patients with metastatic breast cancer in an integrated health care system. Breast Cancer (Dove Med Press) 8: 173-181, 2016.

13. Holohan C, Van Schaeybroeck S, Longley DB and Johnston PG: Cancer drug resistance: An evolving paradigm. Nat Rev Cancer 13: 714-726, 2013.

14. Ohno N, Miura T, Saito K, Nishijima M, Miyazaki T and Yadomae T: Physicochemical characteristics and antitumor activities of a highly branched fungal (1-3)-beta-D-glucan, OL-2, isolated from Omphalia lapidescens. Chem Pharm Bull (Tokyo) 40: 2215-2218, 1992.

15. Chen YT, Lu QY, Lin MA, Cheng DQ, Ding ZS and Shan LT: A PVP-extract fungal protein of Omphalia lapideacens and its antitumor activity on human gastric tumors and normal cells. Oncol Rep 26: 1519-1526, 2011.
16. Livak KJ and Schmittgen TD: Analysis of relative gene expression data using real-time quantitative PCR and the 2(-Delta Delta C(T)) method. Methods 25: 402-408, 2001.

17. Ouyang J, Pan X, Lin H, Hu Z, Xiao P and Hu H: GKN2 increases apoptosis, reduces the proliferation and invasion ability of gastric cancer cells through down-regulating the JAK/STAT signaling pathway. Am J Transl Res 9: 803-811, 2017.

18. Zhang Y, Pan T, Zhong X and Cheng C: Androgen receptor promotes esophageal cancer cell migration and proliferation via matrix metalloproteinase 2. Tumour Biol 36: 5859-5864, 2015.

19. Dou CY, Cao CJ, Wang Z, Zhang RH, Huang LL, Lian JY, Xie WL and Wang LT: EFEMP1 inhibits migration of hepatocellular carcinoma by regulating MMP2 and MMP9 via ERK1/2 activity. Oncol Rep 35: 3489-3495, 2016.

20. Tomizawa M, Shinozaki F, Motoyoshi Y, Sugiyama T, Yamamoto $\mathrm{S}$ and Ishige N: 2-Deoxyglucose and sorafenib synergistically suppress the proliferation and motility of hepatocellular carcinoma cells. Oncol Lett 13: 800-804, 2017.

21. Ma J, Fu G, Wu J, Han S, Zhang L, Yang M, Yu Y, Zhang M, Lin Y and Wang Y: 4-cholesten-3-one suppresses lung adenocarcinoma metastasis by regulating translocation of HMGB1, HIF1 $\alpha$ and caveolin-1. Cell Death Dis 7: e2372, 2016.

22. Edatt L, Haritha K, Sruthi TV, Aswini P and Sameer Kumar VB: 2-Deoxy glucose regulate MMP-9 in a SIRT-1 dependent and NFkB independent mechanism. Mol Cell Biochem 423: 197-206, 2016.

23. Radunovic M, Nikolic N, Milenkovic S, Tomanovic N, Boricic I, Dimitrijevic M, Novakovic I and Basta-Jovanovic G: The MMP-2 and MMP-9 promoter polymorphisms and susceptibility to salivary gland cancer. J BUON 21: 597-602, 2016.

24. $\mathrm{Xu} \mathrm{W}$ and McArthur G: Cell cycle regulation and melanoma. Curr Oncol Rep 18: 34, 2016.

25. Hartwell LH and Kastan MB: Cell cycle control and cancer. Science 266: 1821-1828, 1994.

26. Shen X, Wu Z, Chen S, Chen Y, Xia J, Lv Y and Zhou Y: Induction of G2/M phase arrest and apoptosis by ZGDHU-1 in A549 and RERF-LC-MA lung cancer cells. Oncol Lett 12: 989-994, 2016.

27. Shimura T, Fukumoto M and Kunugita N: The role of cyclin D1 in response to long-term exposure to ionizing radiation. Cell Cycle 12: 2738-2743, 2013.

28. Loukil A, Cheung CT, Bendris N, Lemmers B, Peter M and Blanchard JM: Cyclin A2: At the crossroads of cell cycle and cell invasion. World J Biol Chem 6: 346-350, 2015.

29. Li YL, Zhang J, Min D, Hongyan Z, Lin N and Li QS: Anticancer effects of 1,3-dihydroxy-2-methylanthraquinone and the ethyl acetate fraction of hedyotis diffusa willd against HepG2 carcinoma cells mediated via apoptosis. PLoS One 11: e0151502, 2016.

30. Tamm I, Schriever F and Dörken B: Apoptosis: Implications of basic research for clinical oncology. Lancet Oncol 2: 33-42, 2001.

31. Azadmehr A,Hajiaghaee R, Baradaran B and Haghdoost-Yazdi H: Apoptosis cell death effect of scrophularia variegata on breast cancer cells via mitochondrial intrinsic pathway. Adv Pharm Bull 5: 443-446, 2015.

32. Zhu BS, Zhao K, Jia X, Wu YY and Xing CG: Effects of damage-regulated autophagy regulator gene on the SGC7901 human gastric cancer cell line. Oncol Lett 8: 657-662, 2014.

33. Zhao K, Zhu BS, Gong W, Zhu ML, Gao ZT, Wu YY, Chen Q, Yang XD and Xing CG: SN50 enhances the effects of LY294002 on cell death induction in gastric cancer cell line SGC7901. Arch Med Sci 9: 990-998, 2013.

34. Liu G, Xiang T, Wu QF and Wang WX: Curcumin suppresses the proliferation of gastric cancer cells by downregulating H19. Oncol Lett 12: 5156-5162, 2016.

35. Li H, Xu J, Wang X and Yuan G: Protective effect of ginsenoside Rg1 on lidocaine-induced apoptosis. Mol Med Rep 9: 395-400, 2014.

36. Liu B, Lu Y, Li J, Liu Y, Liu J and Wang W: Leukemia inhibitory factor promotes tumor growth and metastasis in human osteosarcoma via activating STAT3. APMIS 123: 837-846, 2015.

37. Yeh JE and Frank DA: STAT3-interacting proteins as modulators of transcription factor function: Implications to targeted cancer therapy. ChemMedChem 11: 795-801, 2016.

38. Brambilla L, Genini D, Laurini E, Merulla J, Perez L, Fermeglia M, Carbone GM, Pricl S and Catapano CV: Hitting the right spot: Mechanism of action of OPB-31121, a novel and potent inhibitor of the signal transducer and activator of transcription 3 (STAT3). Mol Oncol 9: 1194-1206, 2015. 
39. Khanna P, Chua PJ, Bay BH and Baeg GH: The JAK/STAT signaling cascade in gastric carcinoma (Review). Int J Oncol 47: $1617-1626,2015$.

40. Mukherjee A and Khuda-Bukhsh AR: Quercetin down-regulates IL-6/STAT-3 signals to induce mitochondrial-mediated apoptosis in a nonsmall-cell lung-cancer cell line, A549. J Pharmacopuncture 18: 19-26, 2015.

41. Yu RX, Hu XM, Xu SQ, Jiang ZJ and Yang W: Effects of fucoxanthin on proliferation and apoptosis in human gastric adenocarcinoma MGC-803 cells via JAK/STAT signal pathway. Eur J Pharmacol 657: 10-19, 2011.

42. Huang $\mathrm{C}$ and Xie K: Crosstalk of Sp1 and Stat 3 signaling in pancreatic cancer pathogenesis. Cytokine Growth Factor Rev 23: $25-35,2012$.

43. Kijima T, Niwa H, Steinman RA, Drenning SD, Gooding WE, Wentzel AL, Xi S and Grandis JR: STAT3 activation abrogates growth factor dependence and contributes to head and neck squamous cell carcinoma tumor growth in vivo. Cell Growth Differ 13: 355-362, 2002.

44. Masuda M, Suzui M, Yasumatu R, Nakashima T, Kuratomi Y, Azuma K, Tomita K, Komiyama S and Weinstein IB: Constitutive activation of signal transducers and activators of transcription 3 correlates with cyclin D1 overexpression and may provide a novel prognostic marker in head and neck squamous cell carcinoma. Cancer Res 62: 3351-3355, 2002.
45. Sinibaldi D, Wharton W, Turkson J, Bowman T, Pledger WJ and Jove R: Induction of p21WAF1/CIP1and cyclin D1 expression by the Src oncoprotein in mouse fibroblasts: Role of activated STAT3 signaling. Oncogene 19: 5419-5427, 2000.

46. Ghosh A, Pechota A, Coleman D, Upchurch GR Jr and Eliason JL Cigarette smoke-induced MMP2 and MMP9 secretion from aortic vascular smooth cells is mediated via the Jak/Stat pathway. Hum Pathol 46: 284-294, 2015.

47. Zhang F, Wang Z, Fan Y, Xu Q, Ji W, Tian R and Niu R: Elevated STAT3 signaling-mediated upregulation of MMP-2/9 confers enhanced invasion ability in multidrug-resistant breast cancer cells. Int J Mol Sci 16: 24772-24790, 2015.

() () $\Theta$ This work is licensed under a Creative Common Attribution-NonCommercial-NoDerivatives 4.0 International (CC BY-NC-ND 4.0) License. 